\title{
Technological and engineering equipment as an object of civil rights: intersectoral aspect
}

\author{
Uliana Filatova ${ }^{1}$, Nina Semeryanova ${ }^{2, *}$, and Eugene Vasilev $^{3}$ \\ ${ }^{1}$ Irkutsk State University, Karl Marx str., 1, Irkutsk, 664003, Russia \\ ${ }^{2}$ South Ural State University (National Research University), Nizhnevartovsk Branch, Mira str., 9 , \\ 628600 , Russia \\ ${ }^{3}$ Tyumen Industrial University, Volodarskogo str., 38, Tyumen, 625000, Russia
}

\begin{abstract}
The article considers the main issues of determining technological and engineering equipment as objects of civil rights from the point of view of classifying this category as movable and immovable property. The urgency of the problem of technological and engineering equipment from the point of view of civil turnover is the misinterpretation and assignment of geotechnical objects to the category of movable (immovable) property, which causes a number of problems in practice, leading to unreasonable taxation or unreasonable exclusion of the categories in question as a taxable object.
\end{abstract}

\section{Introduction}

The category "objects of civil rights" is very popular for research. The division of objects into tangible and intangible is not disputed. This classification involves the assignment to material objects - things, works and services, and to non-material - the results of creative activity and personal non-property benefits.

A comprehensive study of the legal category of "civil rights objects" and certain problematic issues were dealt with by such scholars as M.M. Agarkov, A.P. Anisimov, V.A. Belov, S.N. Bratus, O.S. Ioffe, R.S. Bevzenko, A.Y. Ryzhenkov, L.A. Chegovadze, A.Yu. Chikildina et al.

O.S. Ioffe introduced the theory of several levels of the object of legal relations into domestic science. The existence of a common object of legal regulation is substantiated. In particular, O.S. Ioffe writes that the object of civil legal relations, which is at the same time the object of subjective civil rights and civil legal obligations, is intimately connected with the general object of regulation of Soviet civil law. Bevzenko R.S. considered the legal regime of real estate, the problem of qualifying things as immovable. Foreign authors conducted research on the general concept of technology Sazali Abdul Wahab, Raduan Che Rose, Suzana Idayu Wati Osman.

However, the practical use of individual objects of civil rights in property turnover allows identifying the shortcomings of the rules on objects of civil rights. For example, various approaches to the definition of technological and engineering equipment as movable and immovable property give rise to certain problems of law enforcement, which

*Corresponding author: a.copytowa@yandex.ru 
negatively affects the activities of organizations and undermines the stability of civil turnover.

The purpose of the work is to search for meanings and mechanisms to understand the classification of objects of technological and engineering equipment into the category of movable and immovable property, which will allow applying appropriate regulation to these categories of objects. The novelty of the research lies in the formulation, justification and solution of the tasks of determining and classifying such a specific object as technological and engineering equipment into the category of movable and immovable property. The empirical basis of the work consisted of existing civil law and established judicial practice.

Modern conceptual approaches to the definition of the category of objects of civil rights, the study of the peculiarities of their legal regulation made it possible to draw a number of significant conclusions. Engineering equipment is always an immovable thing, since it is intended to serve another, main thing, and is related to it by general purpose (belonging), follows the fate of the main thing, unless otherwise stipulated by the contract. Technological equipment may have a different civil law regime, depending on the type of specific equipment. The equipment which belongs to buildings and structures is functionally connected with them, and its movement is not possible. This equipment appears in civilian circulation as a complex of structurally articulated objects, is a complex thing and is a thing of belonging, and therefore follows the fate of the main thing and obeys its legal mode. In addition, technological equipment may be part of a single immovable complex, which, in accordance with Article 133.1 of the Civil Code, is an immovable that participates in the turnover as a single object. In all other cases, technological equipment is a movable thing, which predetermines its tax regime.

\section{Methods}

The following scientific methods were used in the work: dialectics, analysis, synthesis, deduction, formal legal method, comparative legal method.

Dialectics allowed pushing off from general theoretical ideas and finding a place for technological and engineering equipment in the general system of civil law objects. Analysis and synthesis allowed identifying the structure, composition, properties, signs of technological and engineering equipment, as well as giving them a concept, categorized as movable and immovable property.

\section{Results}

According to article 128 of the Civil Code of Russian Federation [3] objects of civil rights include things, including cash and documentary securities, other property, including noncash money, non-documentary securities, property rights; results of work and provision of services; protected results of intellectual activity and equated to them means of individualization (intellectual property); intangible benefits.

From the point of view of civil law, engineering and technological equipment are related to things, but their legal regime varies depending on the specifics of each thing. The difference of the legal regime, namely the assignment of a thing to a movable or immovable, main thing or property significantly affects the tax burden imposed on the owner of the property. The tax authorities, depending on their own qualifications of the designated objects, move as movable or immovable to pay taxes and also raise the question of qualifying engineering and special technological equipment as immovable, contrary to 
the signs of immovable property generally accepted in civil studies in order to increase the taxable base.

The term engineering equipment does not have a legal definition, but its regulatory acts contain a list of it, which includes a diverse number of items, taking into account the specifics of the main thing. Thus, according to the Regulation on the organization and conduct of reconstruction, repair and maintenance of residential buildings, communal and socio-cultural facilities, approved by order of the State Committee on Architecture and Construction of November 23, 1988 No. 312, engineering equipment includes water supply and sewage (including toilet bowls and sinks), hot water supply, central heating and piping, garbage chutes, gas equipment, electrical equipment, equipment of joint dispatcher systems, external engineering networks, external beautification.

The term "technological equipment" is also not legally fixed, but only its specific names are listed in the Government Order "On Approving the List of Main Process Equipment Used in the Case of Applying the Best Available Technologies to Use Subclause 5 of Clause 1 of Article 259.3 of the Tax Code of the Russian Federation” [4].

Engineering equipment and special technological equipment is not only an object of civil rights, but also an object of taxation.

According to paragraph 1 of Art. 374 of Tax Code of the Russian Federation [5] in the current edition (as amended by the Federal Law of April 2, 2014 N 52-FZ), the objects of taxation for corporate property are both movable and immovable property recorded on the balance sheet as fixed assets in the manner established for accounting (unless otherwise provided by the article. Articles 378 and 378.1 of the Tax Code of the Russian Federation). From 1 January 2019, the Federal Law of 03.08.2018 No. 302 makes changes to clause 1 of Article 374: Only immovable property will be recognized as objects of taxation.

In the Federal Law dated November 29, 2012 No. 202 clause 4 of Art. 374 of the Tax Code of the Russian Federation are supplemented by sub-paragraphs 3-8. Therefore, starting from January 1, 2013 on the basis of paragraphs. 8 p. 4 of Art. 374 of the Tax Code of the Russian Federation, objects of movable property, registered as fixed assets from January 1, 2013, were not recognized as an object of taxation on the property of organizations.

The list of fixed assets included in depreciation groups is regulated by the Decree of the Government of the Russian Federation of January 1, 2002 No. 1 (as amended on April 28, 2018) "On the Classification of Fixed Assets Included in Depreciation Groups"[6].

a. movable property

Further, in order to apply paragraphs. 8 p. 4 of Art. 374 of the Tax Code, first of all it is necessary to establish whether the technological equipment (machine) is movable or immovable property. Since the norms of the Tax Code do not disclose the concepts of "movable property" and "immovable property", let us turn as provided for by the norm of Clause 1, Article. 11 of the Tax Code, to the norms of civil law.

According to paragraph 1 of Art. 130 of the Civil Code of the Russian Federation immovable things (real estate) include plots, subsoil plots and everything that is firmly connected with the land, that is, objects, which movement is impossible without disproportionate damage to their purpose, including buildings, structures, and unfinished construction objects. In this norm, in the definition of real estate lawmaker repels from the natural properties of things, namely, their ability or inability to move. In this regard, the land in Roman law was considered as the only independent real estate. Everything else was considered as things related to it by nature or artificially related to it. This category of things (res soli) was included in the concept of real estate on the basis of the formula "superficies solo credit" all things towering above the earth's surface and closely related to it, follow the earth's surface[7]. Thus, Roman law established the concept of the main thing and the property of belonging, where the land plot acted as the main thing, and everything 
on it was elevated due to the natural properties or the artificial structure was considered to belong to the main thing. This concept was accepted by German and French law. However, despite the fact that Russia belongs to the countries of the Romano-Germanic legal family, the Russian civil code refers residential and non-residential premises to immovable things, as well as parts of buildings or structures (parking spaces) intended to accommodate vehicles, if such premises, parts of buildings or structures are described in accordance with the procedure established by legislation on state cadastral registration. In addition, the Russian law, bypassing the sign of the natural properties of things, refers to immovable things also air and sea vessels subject to state registration, inland navigation vessels, leaving this list open and the right to refer other property to immovable things. So, according to the law, space objects belong to real estate. [8], enterprises (as a set of all types of property intended for its activities, including land, buildings, structures, equipment, inventory, raw materials, products, claims, debts, as well as rights to designations, individualizing the enterprise, its products, works and services (commercial designation, trademarks, service marks), and other exclusive rights, unless otherwise provided by law or contract) [9], a single immovable complex (a set of buildings, structures and other things united by a single purpose, inextricably connected physically or technologically, including linear facilities (railways, power lines, pipelines and others) or located on the same land plot, if in the unified state register rights to immovable property are registered ownership of the totality of these objects as a whole as one real estate) [10].

Things not related to real estate, including money and securities are recognized as movable property. Registration of rights to movable things is not required, except for the cases specified in the law (clause 2 of article 130 of the Civil Code of the Russian Federation).

The concept of real estate in terms of civil law is inextricably linked with the need for state registration of rights to such property (article 131, paragraph 2 of article 223 of the Civil Code of the Russian Federation, etc.).

Thus, the process equipment itself does not belong to real estate by law or by virtue of its physical properties, is movable and, if it is accepted on the balance sheet as an asset, after 01.01.2013 it is not recognized as an object of taxation on the property of organizations on the basis of sub 8 p. 4 of Art. 374 TC RF.

However, in practice there are situations when technological and engineering equipment may be part of a complex thing. In this situation, it is necessary to determine whether movable property is an integral part of real estate. In this case, the Ministry of Finance of Russia strongly recommended to take into account the provisions of the Federal Law No. 384 dated December 30, 2009 "Technical Regulations on the Safety of Buildings and Structures" [11] and the All-Russian Classifier of Fixed Assets (approved by the State standard of Russia dated December 26, 1994 No. 359).

For the purposes of Federal Law No. 384, a building is recognized as a result of construction, which includes premises, as well as a combination of pipelines, communications and other facilities designed for water supply, sewage, heating, ventilation, air conditioning, gas supply, electricity supply, communications, information management, waste disposal, vertical transport (elevators, escalators) or security (sub. 6, 20, 21, paragraph 2, article 2 of the law No. 384, paragraphs 54-58 of the introduction to the AllRussian Classifier of Fixed Assets).

The construction is the result of construction, which is a three-dimensional, planar or linear construction system, having a ground, elevated and (or) underground parts, consisting of supporting and, in some cases, enclosing building structures and intended to perform various types of production processes, storage of products, temporary stay of people, movement of people and goods (subclause 23, paragraph 2, article 2 of Law No. $384)$. 
As we see, for buildings, a set of engineering facilities is integral, while in construction it may be missing. However, quite often the buildings still contain various objects (paragraph 59-70 of the introduction to the All-Russian Classifier of Fixed Assets).

On the basis of the above, it is possible to identify the signs, which presence makes the movable property a part of real estate:

- it relates to the objects specified in subparagraphs 20,21 of paragraph 2 of Article 2 of Law No. 384;

- it is functionally related to real estate;

- its movement is impossible without causing disproportionate damage to the purpose of real estate.

Thus, if movable property corresponds to the listed characteristics, then, together with real estate, it is a complex of structurally articulated objects (a single constructive object of real estate). This complex is taken into account as one inventory item of fixed assets and is subject to property tax [12].

Movable property is not part of the real estate, if at the same time:

- it is accounted for as a separate (independent) inventory item of fixed assets that does not require installation;

- it can be used outside the property;

- its dismantling will not cause disproportionate damage to its purpose and (or) its purpose is not an integral part of the operation of the immovable property.

In this case, movable property is not taxed, provided that it is registered in the composition of fixed assets after January 1, 2013. The assignment of a specific asset in accordance with the All-Russian Classifier of Fixed Assets to machinery and equipment, according to financiers, means its recognition as movable property (the above-mentioned letter of the Ministry of Finance of Russia No. 03-05-05-01 / 56232). And this, in turn, leads to the neglect of its value in determining the taxable base for property tax.

Some types of industrial process equipment can function only if they are installed on a special foundation.

Production equipment installed on special foundations cannot be moved without disproportionate damage to the special foundation and underground utilities. The production equipment itself can be dismantled, transported to another place, mounted again and put into operation. The Ministry of Finance of Russia in the above letter dated February 25, 2013 No. 03-05-05-01 / 5288 indicated the following. The composition of an immovable property, recognized in accordance with the rules of accounting as fixed assets, is determined according to the project documentation and technical passport for it, taking into account subsequent capital investments.

According to the All-Russian Classifier of Fixed Assets, the subsection "Machines and Equipment" includes devices that convert energy, materials and information. The working machines and equipment include all types of technological equipment, including automatic machines and equipment, for the production of industrial products, agricultural equipment, transport, construction, commercial, warehouse, water supply and sewage, sanitary and hygienic and other types of machines and equipment, except energy and informational equipment.

The object of the classification of working machines and equipment is each individual machine, apparatus, unit, installation, etc., including their accessories, instruments, tools, electrical equipment, individual fencing, and foundation.

Production equipment, including those that require fixing on a foundation and suitable for use only as part of a single detached complex, is, in the opinion of officials, not real estate and is not considered as part of a building as an immovable property. If such equipment was registered as fixed assets after January 1, 2013, then it is not subject to corporate property taxation. 
The order of taxation on the property of organizations of special foundations under production equipment depends on whether such a special foundation is an integral part of the building as a property in accordance with project documentation and technical accounting data.

If a special foundation for production equipment is specified in the project documentation and technical accounting documents as part of a building, its cost should be taken into account as part of the original cost of the building. In this case, the cost of work to create such a special foundation will be included in the tax base for property tax of organizations as part of the average annual value of the building.

Otherwise, the cost of creating the specified foundation should be considered as part of the initial cost of production equipment that is movable property.

In some cases, the status of engineering and technological equipment will be affected by the Town Planning Code of the Russian Federation [13], according to the Article 1, transmission lines, communication lines (including line-cable structures), pipelines, roads, railway lines and other similar structures belong to linear objects.

According to the Department of Real Estate of the Ministry of Economic Development of the Russian Federation [14], "linear objects, including underground ones, which are structures put into operation as capital construction objects in accordance with Article 55 of the Town Planning Code of the Russian Federation, are very likely to belong to real estate. Linear objects that are not commissioned in this order are most likely not real estate." It is puzzling that the probabilistic, presumptive nature of the judgments of representatives of the Ministry and their justification is not based on the norms of existing civil law, which directly enshrines the signs of real estate, but on the order of commissioning.

It should be noted that some types of linear objects will be real estate due to legal provisions, such as linear cable communication structures, which are engineering infrastructure objects created or adapted to accommodate communication cables, in accordance with Article 8 of the Federal Law on July 7, 2003 N 126 "On Communications", refer to real estate.

b. judicial practice:

When classifying an object as movable or immovable property judicial practice takes into account whether this object is firmly connected with the land [15].

However, an analysis of judicial practice leads to the conclusion that a strong relationship with the land is not the only sign that an object can be attributed to real estate. In particular, when deciding on the recognition of an object as an immovable, the following issues are clarified:

- whether a thing is a part of another thing (if dissimilar things form a single whole, which implies using them for a general purpose, they are considered as one thing (a complex thing) (Article 134 of the Civil Code of the Russian Federation));

- whether the thing is belonging to another main thing (the thing intended to serve the other (main) thing and related to it by general purpose (belonging) follows the fate of the main thing, unless the contract provides otherwise (Article 135 of the Civil Code of the Russian Federation) [16].

- whether the object has the ability to act in civilian circulation as separate objects of civil rights. [17]

Thus, the decision on the classification of a particular object to movable or immovable property depends on the specific circumstances and characteristics of the specified object.

\section{Discussion}

The issue of turnover of objects of civil rights is debatable in the Russian law. According to E.Yu. Andreeva, the latest trends in the development of domestic legislation, the 
improvement of judicial practice allow to judge the dynamics of the classical theory of objects of civil rights, developed by both pre-revolutionary and Soviet civilists. [18] The problem is complicated by an ambiguous understanding of such categories as "turnoverability" and "legal regime". In the doctrine and legislation, these two concepts are often identified. However, according to $\mathrm{Yu}$.V. Vinichenko, in contrast to the legal regime, which reflects the legislatively established opportunities and responsibilities of subjects in relation to one or another type of objects, turnover-ability is a characteristic of the objects of reality itself - whether they have a natural property to be subject to turnover. [19] The issue of the definition of engineering and technological terminology is familiar not only to lawyers, a misunderstanding of these definitions leads to a wrong translation and, as a result, a misunderstanding and practical mistakes in production. T.V. Parshina indicates this problem in her study; in her opinion, knowledge of technical terminology as a component of the special component of translation competence, forms the fundamental basis for understanding the technical essence of the term, its literate translation. It is necessary to agree with this opinion, since a correct understanding of the essence of things and the onset of the expected legal consequences depend, among other things, on the presence of industry terminology. In order to fully utilize production technologies and predict the results of applying these technologies, it is necessary to rely on their terminological component.

\section{Conclusion}

Thus, engineering equipment is always an immovable thing, since it is intended to serve another, main thing, and is associated with it with a general purpose (belonging), follows the fate of the main thing, unless the contract provides otherwise.

Technological equipment can have a different civil law regime, depending on the type of specific equipment. The equipment belonging to buildings and structures is functionally connected with them and its movement does not seem possible to act in civilian traffic as a complex of structurally articulated objects, is a complex thing and is a thing of belonging, and therefore follows the fate of the main thing and obeys its legal regime. In addition, technological equipment may be part of a single immovable complex, which, in accordance with Article 133.1 of the Civil Code, is an immovable property that participates in the turnover as a single object. In all other cases, technological equipment is a movable thing, and it predetermines its tax regime.

\section{Acknowledgement}

The work was supported by Act 211 of Government of the Russian Federation, contract No 2 A03. 2111

\section{References}

1. Y.V. Truntsevsky, I.I. Lukiny, A.V. Sumachev, A.V. Kopytova, MATEC Web of Conferences 170, 01067 (2018) DOI: 10.1051/matecconf/201817001067

2. D. Izvin, V. Lez'Er, A. Kopytova, MATEC Web of Conferences 170, 01065 (2018) DOI: $10.1051 /$ matecconf/201817001065

3. V. Lezier, M. Gusarova, A. Kopytova, IOP Conference Series: Earth and Environmental Science 90(1), 012069 (2017) DOI: 10.1088/1755-1315/90/1/012069

4. N. Zotkina, M. Gusarova, A. Kopytova, Advances in Intelligent Systems and Computing 692, 1204-1213 (2018) DOI: 10.1007/978-3-319-70987-1_129 
5. Russian Federation, Collection of the Legislation of the Russian Federation 32, 3301 (1994)

6. Government of the Russian Federation, Collection of the legislation of the Russian Federation 27, 4063 (2017)

7. Russian Federation, Collection of the legislation of the Russian Federation 32, 3340 (2000)

8. Government of the Russian Federation, Collection of Legislation of the Russian Federation 1(2), 52 (2002)

9. A.V. Kudukhov, Perfection of civil-law regulation of the state registration of rights to real estate and transactions with it, dissertation (Vladikavkaz, 2011)

10. Law of the Russian Federation of 08/20/1993 N 5663-1

11. Federal Law of Russian Federation of 30.11.1994 No. 51-FZ

12. Federal Law of Russian Federation of 30.11.1994 No. 51-FZ

13. Federal Law of Russian Federation of 30.12.09 No. 384

14. Ministry of Finance of Russian Federation, Bulletin of normative acts of federal executive bodies 20 (2001)

15. Federal Law of the Russian Federation of 29.12.2004 No. 190-FZ

16. E.Yu. Andreeva, News of the Russian State Pedagogical University named after A.I. Herzen 1, 255 (2011)

17. Government of the Russian Federation, Collection of the Legislation of the Russian Federation 1(2), 52 (2002)

A. A. Kopytova, MATEC Web of Conferences 106, 08056 (2017) DOI: $10.1051 /$ matecconf $/ 201710608056$

18. Government of the Russian Federation, Collection of Legislation of the Russian Federation 27, 4063 (2017)

19. A. Kopytova, Procedia Engineering 165, 1132 (2016) DOI: 10.1016/j.proeng.2016.11.830 